\title{
Ethnic Identity and Educational Outcomes in African American College Students
}

\author{
Qua Miller \\ Alvin Akibar \\ Dr. Yolanda Flores Niemann
}

\begin{abstract}
The present study examines social support among African American university students attending a PWI (Primarily White Institution) in transition from a PWI to an MSI (Minority Serving Institution). While college students are vulnerable to psychological distress (PD), African American students face increased risk of PD due to their marginalized status. Evidence suggests that ethnic identity can serve as both a protective and risk factor for PD, potentially increasing resolve in the face of adversity, or conversely leading to hypervigilance. The present study examines PSS (Multidimensional Scale of Perceived Social Support) on Academic Performance. Participants $(\mathrm{N}=225)$ include African American university students recruited as part of a larger study of identity and health behaviors. Initial results indicated that PSS negatively relates to $\mathrm{PD}$, while EI was not significantly related. Implications of results for a University experiencing an increase in ethnic diversity are discussed.
\end{abstract}

Bitensky (1991) describes education as an essential element of freedom and the preserver of democracy. He elaborates that without proper education of the people, the nation would suffer economically and politically. However, what if educational opportunities are disproportionately allocated to certain groups? For African Americans, the harmful impacts of withholding educational opportunities still persist (Pitre, 2014). The disparity in academic achievement can be seen in graduation rates, grade point average (GPA), and scores on standardized test. The National Assessment of Educational Progress (NAEP) reported underperformance from African American students as early as the $4^{\text {th }}$ grade (Vanneman et al., 2009).

During some eras of United States history, education facilitated and increased educational disparities, especially by serving as a tool to force marginalized cultures to assimilate into the "dominant" white culture (Blau, 2004). For example, the Carlisle Indian Industrial School was developed to teach the indigenous population to assimilate and be productive in white society, while discounting the indigenous culture as backward and savage (Loring, 2009). Discussing her own schooling, Loring observed that her teachers often perceived progress as assimilation into the socially dominant culture. Students of Color, like Loring, were, for the most part, ignored. Loring infers that the omission of Native American culture has contributed to the sense of low self-esteem, lack of peer respect, lower high school graduation rates, and lower college retention rates among the 
Indigenous population. Even in schools where the Native American populations were the majority, students who possess this marginalized identity still demonstrated increased psychological distress and feelings of exclusion (Loring, 2009).

Similar to the Native American experience, African Americans have faced prejudice, discrimination, and racism in the education system. The pervasiveness of racism has severely reduced African American students' academic opportunities and outcomes. For instance, until the late $20^{\text {th }}$ century, individuals with African ancestry were blocked from equal access to education through state and federal laws (Jordan, 2014; Kluger, 2011). Plessy v Ferguson (1896) ensured that schools could maintain separate educational institutions for White people and People of Color (POC). Afterward, Brown v. Board of Education (1954), which overturned the "separate but equal" precedent set by Plessy v. Ferguson (1896), would be considered a landmark case for equality in education (Tushnet, 1994). Guinier (2004) describes the Brown court ruling as a golden standard, such that discrimination based upon race was deemed unconstitutional. However, with the passage of time, new Supreme Court justices, and the adoption of colorblind rhetoric, the oncepowerful call for social equality was mitigated into an alibi not to act (Guinier, 2004).

Despite the laws in place to counter systematic prejudice and discrimination, educational opportunities remain unequal (Pitre, 2014). Perhaps the Brown case could not account for the implicit biases held by educators and educational institutions. These biases manifest in the classroom, affect disparities, and sponsor differential treatment among marginalized ethnic groups (Ferguson, 2003). Thus, African American students are often overrepresented in remedial and vocation courses (Boykin \&
Noguera, 2011). Conversely, these students are underrepresented in honors courses and college-prep courses (Darling Hammond, 2010).

Ferguson (2003) finds that even with equivalent educational backgrounds, Black children typically demonstrate decreased performance and a significant test-gap difference to their white counterparts. Environmental factors such as teachers' perceptions and expectations of students, which can be biased by racial generalizations, have a significant role in in the score disparities (American Psychological Association [APA], 2012). The APA (2012) defines educational disparities as unjust and unfair differences in education. For White and Black students this disparity exists across language, reading, and math. Similarly, Weinstein, Gregory, \& Strambler (2004) found that biased teacher expectations can harm a student's academic performance, particularly for students with a marginalized identity.

DeCuir \& Dixson (2004) used anecdotal evidence and critical race theory (CRT) to analyze the experiences of two African American students --Barbra and Malcolm -- attending a primarily white high school. DeCuir \& Dixson (2004) describe the school, Wells Academy, as an affluent educational setting that celebrates diversity. Students attending this school often come from money, but there are students from less affluent areas that attend the school. Barbra and Malcom come from upper middle class and middle-class families, respectively. Despite the presence of a diversity coordinator and attempts to celebrate diversity, the students still felt culturally isolated, physically isolated, and "uncelebrated." Malcolm, who is on the discipline committee, was overruled by his principal when Malcolm's committee decided to expel a student for threats and 
hate speech. Instead, the student received a month suspension and was welcomed back to school. DeCuir \& Dixson (2004) use a critical race perspective to question what climate would allow an individual to feel comfortable with making racially charged comments. DeCuir \& Dixson argue that race is salient in the classroom and that racism has become normalized and even expected within the cultural climate of Wells Academy. The racism Barbra and Malcolm continuously battled was not overt or rare. Rather it was common and covert in both practices and policies. Microaggressions - defined by Pierce et al. (1977) and Sue (2010) as backhanded comments, often disguised as compliments, that refer to a person's marginalized status - are a "newer" form of racism that can negatively affect a students' educational outcomes, social standing, emotional experiences, and career preparation (Hollingsworth, Patton, Allen, \& Johnson, 2018). These microaggressions represent a type of racism common to everyday experiences of African American students (Sue, 2010).

\section{Alternative Educational Institutions}

African Americans have continuously fought for equity in academia (Albritton, 2012). In fact, historically Black colleges and universities (HBCUs) were formed in the interest of making educational equivalence for Africans Americans (Albritton, 2012). Although HBCUs continue to provide justice, equality, and social mobility for African Americans pursuing education (Albritton, 2012), the longstanding inequality in education continues to be reflected in performance gaps between ethnic groups. For instance, historically marginalized group members within education systems (excluding some Asian American populations) who attend
Predominately White Institutions (PWIs) are: less likely to graduate college in five years; have lower grade point averages; higher dropout rates; and lower entrance rates into graduate programs compared to White students (Aud et al., 2010; Hollins, King \& Hayman, 1994; Jencks \& Phillips, 1998; King, 2005; National Assessment of Educational Progress [NAEP], 2011; National Center for Educational Statistics [NCES], 2010).

African American students attending

HBCUs often demonstrate superior academic outcomes compared to their counterparts in PWIs (Smedley, Myers, \& Harrell, 1993). This finding is consistent with research conducted by Flowers (2002) and Outcalt \& Skewes-Cox (2002), which demonstrated that HBCUs have a significant contribution to successful academic outcomes for African American students. Although in the present study we are not directly comparing PWIs to HBCUs, it is important to consider the historical legacy of the institutions and the implications for everyday experiences of their students. As campuses increase in racial diversity, the need for inclusivity of Students of Color becomes increasingly important. PWIs and HBCUs represent opposite ends of the spectrum with the former being historically exclusive towards African American students and the latter being historically inclusive of African American students. Harper and Hurtado (2007) found that African American students often feel excluded at PWIs. Other work indicates that perceived social support, which is defined as a perceived resource of the individual applied by confiding in associates, social domains, and the community (Lin, Dean, \& Ensel ,1986 ; Jay \& D'Augelli, 1991), plays an important role in academic achievement (Baldwin, Chambliss, \& Towler, 2003; Skowron, Wester, \& Azen, 2004). 
In general, students' educational experiences can be moderated by feelings of inclusivity, environmental factors, and affirmation towards the institution (Brandon, 2014). Additionally, high expectations on students from instructors can have a positive impact on the college experience (Chickering \& Reisser, 1993; Education Commission of the States, 1995; Kuh, 2001; Kuh, Schuh, Whitt \& Associates, 1991; Pascarella, 2001; Pascarella \& Terenzini, 1991). However, African American students who routinely perceive racism (PR) at their institution are more likely to correlate PR with feelings of social isolation, stress, and dissatisfaction (Gloria et al, 1999; Feagin, Vera, \& Imani, 1996; Pascarella \& Terenzini, 1991). Moreover, students attending PWIs experience increased levels of racism on campus when compared to their HBCU counterparts (Feagin, Vera, \& Imani, 1996; Pascarella \& Terenzini, 1991). It is important to note that Wilson (2007) found that HBCUs have contributed significantly the development of African American professionals, despite their limited resources.

\section{Role of Ethnic Identity: Risk or Protective Factor}

Before discussing the role of ethnic identity as a protective or risk factor for students, it is important to acknowledge that the function of racial identity and ethnic identity is inconsistent in the literature (Cokley, 2007). For instance, Sellers \& Shelton (2003) hypothesized that certain aspects of racial identity/ethnic identity/socialization have different functions and that their role in moderating psychological distress can vary. They found that individuals with high ethnic/racial identity as one of their core attributes perceived more ethnic/racial discrimination. However, racial ideology and public regard were able to mitigate distress. Their study highlights the multidimensionality of ethnic/racial identity, especially in regard to its relationship with racial discrimination and psychological distress.

A major contributor to the inconsistencies in the literature is partly due to how researchers interchange race and ethnic identity (Cokley, 2007; Trimble 2007). For the present study, racial identity is defined as people who are socially recognized as belonging to a particular group (Helms, 1993). The definition of ethnic identity will refer to more cultural association towards belief and value (Phinney, 1996). Additionally, ethnicity refers to the combination of both physical and cultural characteristics (Mio, BarkerHackett, \& Tumambing, 2006).

Higher ethnic identity has been associated with lower levels of depression and as a protective factor or buffer against perceived discrimination (Mossakowski, 2003). Yet, Pascoe \& Richman (2009) also found that individuals who are strongly associated with their groups are more likely to perceive discriminatory events, whereas individuals with lower affiliation to their respective groups may not ascribe specific actions to racism or racial discrimination. On the other hand, Noh, Beiser, Kaspar, Hou, \& Rummens (1999) found that higher levels of ethnic identity and depression increased the relationship between perceived discrimination and depression. Thus, a higher level of a stigmatized identity can lead to hypervigilance. Additionally, Branscombe, Schmitt, \& Harvey (1999) found that continuous discrimination would increase the level of association with other members of the same racial group. Thus, increased racial discrimination may connect to a stronger ethnic identity.

Brondolo, Halen, Pencille, Beatty, \& Contrada (2009) theorize that ethnic and racial identity serve to increase cultural 
pride and commitment to one's group.

Strong ethnic identity also can help persons develop tactics for dealing with

discrimination. Yet, strong identity can only be protective in a certain context. Brondolo et al. (2009) found that strong identity alone is not enough to diminish the effects of racism on the development of depressive symptoms. In some circumstances, strong identity may increase the awareness of threat and harm. Thus, other contextual factors moderate the function of racial/ethnic identity; such that, outcomes could be impacted by how white individuals choose to interact with African Americans, especially for African Americans with a higher ethnic/racial identity.

\section{General College Stressors}

Stallman (2010) found that psychological distress (e.g., elevated anxiety, worry, depression) was reported more for college students than for the general population (eighty-four percent vs. twenty-nine percent). Across all ethnic/racial groups, college students face similar stressors. General stressors that college students experience include the rigor of studies, relationship history with family, peers, and significant others, and financial status (Gerdes \& Mallinckrodt, 1994), which may affect academic outcomes. For instance, Keogh, Bond, \& Flaxman (2006) found that increased anxiety and worry interfere with the working memory and can lead to lower testing performance. However, being a member of a racial/ ethnic underrepresented group creates the opportunity for additional stressors, which can lead to "minority stress" and create pathways to maladjustment (Smedley, Myers, \& Harrell 1993).

Current literature has not fully examined the role that ethnic identity plays in a college student's life, especially for
Students of Color in Predominantly White Institutions (PWIs). Racial stressors are in the everyday lives of ethnic minority students and should be taken into consideration whenever one tests for psychological distress in college studies (Greer, 2008).

\section{Minority Stress and Psychological Distress}

Minority stress, defined as regularly occurring stress as a result of prejudice and discrimination of a marginalized status (Smeadly, Meyers, \& Harrell, 1993), makes a substantial contribution to the correlation between stress and psychological distress (Smeadly, Meyers, \& Harrell, 1993). Minority stress can create academic vulnerability and takes a toll on students' coping resources (Smeadly, Meyers, \& Harrell, 1993). These stressors are not new to African Americans, who, as a group have had to cope and process racial microaggressions for a significant extent of time (Kaiser \& Miller 2001). The damages of these racial slights extend beyond the comment made. In fact, time and energy are depleted via the process of determining if there was, indeed, a microaggression, if the comment had racist intent, and how to respond to the comment (Sue, 2010). Additionally, increased racial discrimination has been correlated with lower perceived social support and greater depressive symptoms (Prelow, Mosher, \& Bowman, 2006). Potential long-term effects of minority stress should be taken into consideration, especially for African American men. Huang, \& Franklin, (2011) have found that the higher the education of African American men, the more likely they are to encounter and perceive stressful environments. A contributing factor to this trend could be that strong social support was found to be less available for members of 
stigmatized groups (Cole et al., 2007). Further, while underrepresented students expressed similar optimistic expectations regarding academic success, they are at increased risk for more deficient academic performance, in comparison to white peers (Cole, Matheson, \& Anisman, 2007).

\section{Hypervigilance and Racial Battle Fatigue}

African American students face constant racial stressors including racial slights, recurrent indignities, irritations, unfair treatment, stigmatization, hypersurveillance, and contentious classrooms to personal threats or attacks on one's wellbeing (Smith, Allen, \& Danley, 2007). Increased hypervigilance to racism and discrimination can lead to a perceived stressful environment, exhaustion, loss of self-control, ambiguity, strain, frustration, and injustice (Smith, Yosso, \& Solórzano, 2011). Chronic racial tension can be described as Racial Battle Fatigue (RBF). $\mathrm{RBF}$ is the strain of stressors on marginalized groups of people and the energy they must use to cope and "battle" against discrimination (Smith et al., 2007). RBF has been linked to combat stress syndrome (Smith, Hung, \& Franklin, 2011). Individuals living with these syndromes are living and working in environments of heightened distress. For both phenomena, there is a constant sense of alert or danger because of the perception that one's life, personal dignity, or character is being threatened (Pierce, 1974, 1975a, 1975b, 1995; Shay, 2002; Shay \& Munroe, 1999; U.S. Department of the Army, 1994). Likewise, African Americans with RBF must live with constant environmental stressors in the hostile/unsupportive environment (Smith, Hung, \& Franklin, 2011).

\section{Present Study}

The current study aims to examine the role of social support and ethnic identity against the effect of psychological distresses.

The location for the present study, a large southwestern university, which will be referred to in this paper as University X, has experienced an increase in racial diversity. Forty-five percent of students reported underrepresented racial identities, as recorded by University X Division of Equity and Diversity 2017 (excluding students that identified as Non-Resident Alien and Unknown). Once a single racial minority group reaches twenty-five percent of the student body, the institution is eligible to apply for MSI (Minority Serving Institution) status and funding, according to the Department of Education.

What does classification as an MSI mean for African American students? Does the mere number of Students of Color make a university more inclusive? Might student diversity be reflected in faculty diversity? According to the University X Division of Equity and Diversity (2017), White students make forty-eight percent of the student population, while African Americans make up fourteen percent of the population. In terms of faculty positions, less than five percent of faculty member identified as African American, while approximately 70 percent of faculty members identified as White.

As a national comparison, the NCES (2015) reported that on average, fifty eight percent of college students identified as white, while fourteen percent of college students identified as African American. From 1976 to 2015 the percentage of Black students attending a university has increased by four percent, which is the lowest among other comparable ethnic minorities, e.g, Latinx (NCES, 2015). 


\section{Primary Hypotheses}

The present study examined the effects of social support, psychological distress, and ethnic identity among African American college students at a PWI that is experiencing an increase in racial diversity. Specifically, the hypothesizes of the present study are:

H1: The relationship between ethnic identity and academic performance is mediated by psychological distress.

$\mathrm{H} 2$ : The relationship between ethnic identity and psychological distress is moderated by perceived social support.

\section{Method}

\section{Participants}

Most of the participants indicated their gender as female $(77.1 \%)$, cisgender $(99.6 \%)$, and were in their late teens or early twenties $\left(M_{\text {age }}=20.56, S D=2.10\right)$. For sexual identity, participants self-identified as heterosexual (83.6\%), bisexual $(7.5 \%)$, gay/lesbian/homosexual (4.4\%), pansexual (2.6\%), asexual (1.1\%), and two percent of participants were questioning or unsure of their sexual identity. With respect to race, we used only participants that identified as Black/African American/African, which was a $\mathrm{N}$ of 222 ( roughly $16.46 \%$ of participants in the primary study).

\section{Measures}

Ethnic Identity. Multi-group Ethnic Identity Measure-Revised (Phinney, 1992), has been measured over various ethnic population and age groups and has demonstrated consistent reliability with alphas above .80 . The MEIM-R is a12 question measure that assess ethnic identity search and commitment, using a four-point
Likert scale that ranges from strongly agree to strongly disagree.

Psychological Distress. The Center for Epidemiologic Studies Depression Scale is a self-report scale that measures depressive symptoms and has been used to validate longer scales. The measure has demonstrated high internal consistency. Across various demographic groups the CES-D has demonstrated consistent reliability, validity, and factor structure. Radloff (1977) reported alphas of .80 or above for all demographic groups. The selfreport scale that records the frequency of feelings and behaviors to assess depressive symptomologye ranges from Rarely to Most of the time.

The Inventory of Depression and Anxiety Symptoms is a self-report measure that assesses symptomology that correlates with major depression and anxiety, across college, psychiatric, and community adult populations. In comparison with other depression and anxiety measures, the IDAS demonstrates strong convergent and discriminant validity. Watson et al. (2007) reported moderate reliability with coefficient alphas at or above .80. The IDAS has several scales that measure numerous symptoms and two broader scales, specifically, the General Depression Scale utilized by this study. The scale rates, from Not at all to Extremely, the frequency of certain feelings and experiences over the course of two weeks.

Social Support. Multidimensional Scale of Perceived Social Support (MSPSS) is a self-report measure that addresses three dimensions of support from family, friends, and significant other. In various studies, the MSPSS demonstrated strong internal and test-retest reliability. According to Hopkins Symptom Checklist, higher levels of perceived social support are correlated with lower levels of depression symptomology, although difference between genders has 
been noted. The MSPSS utilizes a 12 question scale that ranges from Very Strongly Disagree to Very Strongly Agree.

Academic Performance. Self-

Reported Grade Point Average, especially

first semester GPA, has been correlated with

college graduation for underrepresented

students. Numerous studies have

demonstrated that a cumulative GPA can

serve as a reliable predictor of retention and graduation (Attewell, Heil, \& Reisel, 2011;

Mettler, 2011; Reason, 2003).

\section{Procedure}

Participant data was taken from an existing dataset that focused on sexual identity and social anxiety within college students (Akibar, Niemann, Blumenthal, \& Vosvick, 2019). Institutional Review Board approval was acquired prior to recruiting participants and data collection. Recruitment was exclusively through the university SONA system. Students were recruited from psychology, marketing, management, journalism, health, education, development and family studies students, and non -majors taking courses within the listed departments. Courses related to the LGBT Studies minor were specifically targeted, as to increase the probability of recruiting participants with underrepresented sexual identities. The Qualtrics Survey software served as our online method of gathering informed consent and collecting data. Online survey preferences were set to check with participants that any incomplete responses were made purposely, rather than accidentally, as to reduce the amount of data cleaning and careless responses.

\section{Results}

This study utilized Hayes (2013) PROCESS macro to analyze the relationship between ethnic identity and social support, and the relationship between psychological distress and academic performance.

Psychological distress (IDAS \& CES-D) and academic performances were assigned as the Outcome Variables, while ethnic identity was the Independent variable. Additionally, social support was the assigned moderator.

As indicated on Table 1, there was a significant relationship between ethnic identity and psychological distress (CES-D) $(p=.03)$. More specifically, increased levels of psychological distress were positively correlated with ethnic identity exploration and commitment. Also, there was no significant association between PD and social support ( $p=.34$ ), meaning that the level of social support perceived by students did not impact the level of psychological distress reported.

As indicated on Table 1, there was no significant relationship between psychological distress and academic performance $(p=.62)$. Thus, the amount of distress students reported did not predict academic performance. Similarly, there was no significant relationship between ethnic identity and academic performance ( $p=$ .84). Levels of exploration and commitments to one's ethnic identity did not predict students' academic performance.

As indicated in Table 2, there was no significant association between ethnic identity and psychological distress (IDAS) $(p=.48)$. Nor was there any significance between social support and psychological distress (IDAS) $(p=.91)$. Neither the level of exploration and commitments to one's ethnic identity and the amount of social support perceived by students had significant relationships with psychological distress, when using the IDAS.

\section{Discussion}

African American students have lower grade point averages, higher dropout 
rates, and lower entrance rates into graduate programs compared to White students at PWIs. Reasons for this state are varied. For instance, Harder and Hurtado (2007) found that previous exclusionary practices can influence the current climate of an institution. For African Americans, PWI's have served as tools to marginalize and exclude (Harper, 2013). Even when allowed to attend historically white universities, African American students face increased stressors due to their marginalized status (Lambert, 2010). Using a critical race perspective, the present study supports Harper and Hurtado's (2007) finding that African American Students often feel excluded at PWIs.

Again, our hypothesis predicted that the relationship between ethnic identity and academic performance is mediated by psychological distress. Additionally, we predicted that the relationship between ethnic identity and psychological distress is moderated by perceived social support. Results indicated that African American students did not benefit from finding strong sources of support. Increased levels of support from friends, family, and significant others did not mitigate the extraneous stressors faced by African American students' marginalized status. These results partially support Juang et al.'s (2016) finding that social support, from peers and family, was able to buffer somatization of college students, but not depressive symptoms such as loneliness.

Ethnic identity was correlated with PD when using the CES-D as our outcome variable, meaning that the level of exploration and commitments to one's ethnic identity might explain why, on average, our sample scores indicated that they are at risk for clinical depression. However, when using the IDAS as our PD measure, there was no significant relationship. Additionally, there was no relationship between students' academic performance and PD. These results could be explained by previous research conducted by Watson et al. (2007). Their findings state that the CES-D is a more generalizable measurement scale for depression, versus the IDAS, which encompasses multiple subscales. Also, increased levels of exploration and commitment to one's ethnic identity were positively correlated with psychological distress.

In the U.S. the number of African American students has increased in the past decades (Klarman, 2006). However, have college environments changed in sync? At University $X$, the increased diversity at the undergraduate level is not reflected at the faculty or graduate levels. Could this have any implications for experiences, especially for students with a strong sense of ethnic identity?

Research Applications: Results of this study suggest that examining how the historical legacy of the University impacts the current climate could identify potential stressors experienced by African American students. Additionally, resources should be allocated towards empowering the ethnic identity of African American college students, via funding/creating of organizations on campus that support these students - for instance, funding workshops that train students and faculty about prejudice and stereotypes. Another suggestion might be for universities to use focus groups to gauge African American socialization on campus, while identifying harmful stressors experienced by these students. As universities become more ethnically diverse it is important that universities ensure these students are supported. PWIs might also consider allocating more resources towards creating a more inclusive campus environment for African American students. 
Future Research: Future research should investigate other factors, outside of social support, that may help buffer psychological distress experienced by African American college students. Future research might also consider directly testing for racial stressors, in order to gauge with accuracy the experiences of African American college students, while controlling for variables like perceived discrimination, frequency of microaggressions, colorblind attitudes, etc. Additionally, moving away from self-report measures might allow researchers to capture the experiences of marginalized individuals more accurately. It is important to note that we did not control for individuals with multiple marginalized identities. Individuals tend to hold a collection of identities that interact with each other; thus, identifying with two or more marginalized identities may face increased discrimination across multiple identities. Therefore, future research should examine how identities such as sexuality, gender, multiracial identities, etc., impact a student's perception of discrimination on campus. Males, gender and sexual minorities were underrepresented in the sample. Future studies may expand on intersectionality of identities within this context.

\section{Limitations}

Possible errors could stem from the choice of model or our measurement of psychological distress. Additionally, this study was a secondary analysis, and we were unable directly to test the extent of racial stressors experienced by students. Future directions for researchers for researchers would be to directly measure the campus culture.

\section{References}

Ahmed, Z., \& Julius, S. H. (2015).

Academic performance, resilience, depression, anxiety, and stress among women college students. Indian Journal of Positive Psychology, 6(4), 367. Retrieved from

http://pitt.idm.oclc.org/login?url=htt p://search.proquest.com/docview/177 9457306? accou ntid=14709

Akibar, A., Niemann, Y.F., Blumenthal, H. \& Vosvick, M. (2019) Dimensions of sexuality and social anxiety in emerging adulthood. Journal of Gay \& Lesbian Mental Health. Advance online publication. DOI:: 10.1080/19359705.2019.1568945

American Psychological Association. (2012). Presidential task force on educational disparities. Ethnic and racial disparities in education: Psychology's contributions to understanding and reducing disparities. Retrieved from http://www.apa.org/ed/ resources/racial-disparities.aspx

Aronson, J., Fried, C. B., \& Good, C. (2002). Reducing the effects of stereotype threat on African American college students by shaping theories of intelligence. Journal of Experimental Social Psychology, 38(2), 113-125. DOI: $10.1006 /$ jesp.2001.1491

Aud, S., Fox, M., \& KewalRamani, A. (2010). Status and trends in the education of racial and ethnic groups (NCES 2010-015). U.S. Department of Education, National Center for Education Statistics. Washington, DC: U.S. Government Printing Office. Retrieved from https://nces.ed.gov/pubs2010/201001 5.pdf 
Aud, S., Hussar, W., Planty, M., Snyder, T., Bianco, K., Fox, M., Frohlich, L., Kemp, J., \& Drake, L. (2010). The Condition of Education 2010 (NCES 2010-028). National Center for Education Statistics, Institute of Education Sciences, U.S.

Department of Education. Washington, DC.

Blau, J. R. (2004). Race in the schools: Perpetuating white dominance?. Lynne Rienner Publishers. DOI: https://doi:.org/10.1086/491775

Bitensky, S. H. (1991). Theoretical foundations for a right to education under the US Constitution: a beginning to the end of the national education crisis. Nw. UL Rev., 86, 550. Retrieved from https://heinonline.org/HOL/Page?ha ndle $=$ hein.journals/illlr86\&div $=23 \&$ g_sent $=1 \&$ casa token $=15 \mathrm{Fg} 9$ ziDzdU AAAAA:mXRY0nhz5Wn7Ex3qYM fg6tMzirPTTieN3f1XxumjbleHyqeoNtV3fGKL3Eh2MNq6RIWdP yaAg\&collection $=$ journals

Brandon, J. (2014). African-American Male Inclusion, Involvement, Perception and Achievement at Predominantly White Institutions. McNair Scholars Research Journal, 7(1), 5. Retrieved from http://commons.emich.edu/cgi/viewc ontent.cgi article $=1077 \&$ context $=\mathrm{mc}$ nair

Branscombe, N. R., Schmitt, M. T., \& Harvey, R. D. (1999). Perceiving pervasive discrimination among African Americans: Implications for group identification and well-being. Journal of personality and social psychology, 77(1), 135. DOI: https://doi:.org/10.1037//00223514.77.1.135
Brondolo, E., Ver Halen, N. B., Pencille, M., Beatty, D., \& Contrada, R. J. (2009). Coping with racism: A selective review of the literature and a theoretical and methodological critique. Journal of behavioral medicine, 32(1), 64-88. DOI: https://doi:.org/10.1007/s10865-0089193-0

Caldwell, T., \& Obasi, E. M. (2010). Academic performance in African American undergraduates: Effects of cultural mistrust, educational value, and achievement motivation. Journal of Career Development, 36(4), 348369. DOI: https://doi:.org/10.1177/0894845309 349357

Carter, P. L. (2003). "Black" cultural capital, status positioning, and schooling conflicts for low-income African American youth. Social problems, 50(1), 136-155. DOI: https://doi:.org/10.1525/sp.2003.50.1 .136

Cokley, K. O. (2003). What do we know about the motivation of African American students? Challenging the " anti-intellectual" myth. Harvard Educational Review, 73, 524-558. DOI: https://doi:.org/10.17763/haer.73.4.3 618644850123376

Cokley, K., Komarraju, M., King, A., Cunningham, D., \& Muhammad, G. (2003). Ethnic differences in the measurement of academic selfconcept in a sample of African American and European American college students. Educational and Psychological Measurement, 63, 707-722. doi: https://doi:.org/10.1177/0013164402 251055

Cokley, K. (2007). Critical issues in the measurement of ethnic and racial 
identity: A referendum on the state of the field. Journal of Counseling Psychology, 54, 224 -234. doi: https://doi.org/10.1177/00131644022 51055

Cole, B., Matheson, K., \& Anisman, H. (2007). The moderating role of ethnic identity and social support on relations between well-being and academic performance. Journal of Applied Social Psychology, 37(3), 592-615. doi: https://doi.org/10.1111/j.15591816.2007.00176.x

DeCuir, J. T., \& Dixson, A. D. (2004). "So when it comes out, they aren't that surprised that it is there": Using critical race theory as a tool of analysis of race and racism in education. Educational researcher, 33(5), 26-31. doi: https://doi.org/10.3102/0013189x033 005026

Duncan, L. E. (2003). Black male college students' attitudes toward seeking psychological help. Journal of Black Psychology, 29(1), 68-86. Doi: https://doi.org/10.1177/00957984022 39229

Elliott, R., Strenta, A. C., Adair, R., Matier, M., \& Scott, J. (1996). The role of ethnicity in choosing and leaving science in highly selective institutions. Research in Higher Education, 37(6), 681-709. Doi: https://doi.org/10.1007/bf01792952

Feagin, J. R., Vera, H., \& Imani, N. (1996). The agony of education: Black students at White colleges and universities. Psychology Press. Doi: https://doi.org/10.2307/2967354

Ferguson, P. V. (1896). Plessy v. Ferguson. Ferguson, R. F. (2003). Teachers' perceptions and expectations and the Black-White test score gap. Urban education, 38(4), 460-507. Doi: https://doi.org/10.1177/00420859030 38004006

Furr, S.R., Westefeld, J.S., McConnell, G.N., \& Jenkins, J.M. (2001). Suicide and depression among college students: A decade later. Professional Psychology: Research and Practice, 32, 97-100. Doi: https://doi.org/10.1037//07357028.32.1.97

Gerdes, H., \& Mallinckrodt, B. (1994). Emotional, social, and academic adjustment of college students: A longitudinal study of retention. Journal of Counseling and Development, 72, 281-287. Doi: https://doi.org/10.1002/j.15566676.1994.tb00935.x

Gillborn, D. (2005). Education policy as an act of white supremacy: Whiteness, critical race theory and education reform. Journal of Education Policy, 20(4), 485-505. Doi: https://doi.org/10.1080/02680930500 132346

Greer, T. M. (2008). Racial and ethnicrelated stressors as predictors of perceived stress and academic performance for African American students at a historically Black college and university. The Journal of Negro Education, 60-71. Retrieved from https://www.jstor.org/stable/pdf/400 34678.pdf?casa token=JDYtliVjZqs AAAAA:pU8cFGCSeYlVQhzjtH6iP CM9VXoqsseqaBnbZJ8tYM5iz36ua6Msbl3JebOme 0r6mDcgkdffHOhoufJwlcKpYS8H9 0NdaeagTMqpHt_UjpkIaBUuNJg

Guinier, L. (2004). From racial liberalism to racial literacy: Brown v. Board of Education and the interestdivergence dilemma. Journal of American History, 91(1), 92-118. Doi: https://doi.org/10.2307/3659616 
Harper, S. R. (2013). Am I my brother's teacher? Black undergraduates, racial socialization, and peer pedagogies in predominantly white postsecondary contexts. Review of Research in Education, 37(1), 183-211. Doi: https://doi.org/10.3102/0091732x124 71300

Helms, J. E. (1993). An overview of Black racial identity theory. In J. E. Helms (Ed.), Black and White racial identity (pp. 9-32). Westport, CT: Praeger Publishers.

Jacoby-Senghor, D. S., Sinclair, S., \& Shelton, J. N. (2016). A lesson in bias: The relationship between implicit racial bias and performance in pedagogical contexts. Journal of Experimental Social Psychology, 63, 50-55. doi:

https://doi.org/10.1016/j.jesp.2015.1 0.010

Jay, G. M., \& D'Augelli, A. R. (1991). Social support and adjustment to university life: A comparison of african-american and white freshmen. Journal of Community Psychology, 19(2), 95-108. Doi: https://doi.org/10.1002/15206629(199104)19:2\%3C95::aidjcop2290190202\%3E3.0.co;2-2

Jencks, C., \& Phillips, M. (Eds.). (2011). The black-white test score gap. Brookings Institution Press. Doi: https://doi.org/10.2307/20080778

Jordan, W. D. (2014). Historical origins of the one-drop racial rule in the United States. Journal of Critical Mixed Race Studies, 1(1). Retrieved from https://escholarship.org/uc/item/91g7 $61 \mathrm{~b} 3$

Juang, L., Ittel, A., Hoferichter, F., \& Gallarin, M. M. (2016). Perceived racial/ethnic discrimination and adjustment among ethnically diverse college students: Family and peer support as protective factors. Journal of college student development, 57(4), 380-394. Doi: https://doi.org/10.1353/csd.2016.004 8

Keogh, E., Bond, F. W., \& Flaxman, P. E. (2006). Improving academic performance and mental health through a stress management intervention: Outcomes and mediators of change. Behaviour research and therapy, 44(3), 339357. Doi: https://doi.org/10.1016/j.brat.2005.0 3.002

King, J. (Ed.) (2005) Black education: A transformative research and action agenda for the new century. Mahwah, NJ: Lawrence Erlbaum Associates. Doi: https://doi.org/10.4324/97814106139 12

Klarman, M. J. (2006). From Jim Crow to civil rights: The Supreme Court and the struggle for racial equality. Oxford University Press. Doi: https://doi.org/10.1162/jinh.2006.37. 2.312

Kluger, R. (2011). Simple Justice: The History of Brown v. Board of Education and Black America's Struggle for Equality. Vintage. Doi: https://doi.org/10.2307/2148944

Lambert, F. (2009). The battle of Ole Miss: Civil rights v. states' rights. Oxford University Press. Doi: https://doi.org/10.5860/choice.476460

Lin, N., Dean, A., \& Ensel, W. M. (Eds.). (1986). Social support, life events, and depression. Academic Press.

Loring, D. (2009). The Dark Ages of Education and a New Hope: Teaching Native American History in Maine Schools. New England 
Journal of Higher Education, 24(1), 16-17. Doi:

https://doi.org/10.2307/j.ctt1d9njj2.9 8

McDonald, N. L. (2011). African American college students at predominantly White and Historically Black colleges and universities. Vanderbilt University.

McFarland, J., Hussar, B., de Brey, C., Snyder, T., Wang, X., WilkinsonFlicker, S., ... \& Bullock Mann, F. (2017). The Condition of Education 2017. NCES 2017-144. National Center for Education Statistics. Retrieved from https://nces.ed.gov/pubsearch/pubsin fo. asp?pubid $=2017144$

McKown, C., \& Weinstein, R. S. (2008). Teacher expectations, classroom context, and the achievement gap. Journal of school psychology, 46(3), 235-261. Doi:

https://doi.org/10.1016/j.jsp.2007.05. 001

Mio, J. S., Barker-Hackett, L., \& Tumambing, J. (2006). Multicultural psychology: Understanding our diverse communities. McGraw-Hill Humanities Social.

Morrison, R., \& O'Connor, R. C. (2005). Predicting psychological distress in college students: The role of rumination and stress. Journal of clinical psychology, 61(4), 447-460. Doi: https://doi.org/10.1002/jclp.20021 Mossakowski, K. N. (2003). Coping with perceived discrimination: Does ethnic identity protect mental health?. Journal of health and social behavior, 318-331. Doi: https://doi.org/10.2307/1519782

Musu-Gillette, L., de Brey, C., Mcfarland, J., Hussar, W., Sonnwnberg, William., Wilkinson-Flicker, S.
(2016). Status and Trends in the Education of Racial and Ethnic Groups 2016. NCES 2016-007. National Center for Education Statistics.

National Assessment of Education Progress (NAEP) (2009). Washington, DC: US Department of Education.

National Assessment of Education Progress (NAEP) (2011). Washington, DC: US Department of Education.

Nelson Laird, T. F., Bridges, B. K., Morelon-Quainoo, C. L., Williams, J. M., \& Holmes, M. S. (2007). African American and Hispanic student engagement at minorityserving and predominantly White institutions. Journal of College Student Development, 48(1), 39-56. https://doi.org/10.1353/csd.2007.000 5

Neville, H. A., Heppner, P. P., \& Wang, L. F. (1997). Relations among racial identity attitudes, perceived stressors, and coping styles in African American college students. Journal of Counseling \& Development, 75(4), 303-311.

Noh, S., Beiser, M., Kaspar, V., Hou, F., \& Rummens, J. (1999). Perceived racial discrimination, depression, and coping: A study of Southeast Asian refugees in Canada. Journal of health and social behavior, 193-207. Doi: https://doi.org/10.2307/2676348

Palmer, R., \& Gasman, M. (2008). " It takes a village to raise a child": The role of social capital in promoting academic success for African American men at a Black college. Journal of College Student Development, 49(1), 52-70. Doi: https://doi.org/10.1353/csd.2008.000 2

Pascoe, E. A., \& Smart Richman, L. (2009). Perceived discrimination and health: 
a meta-analytic review.

Psychological bulletin, 135(4), 531.

Doi:

https://doi.org/10.1037/a0016059

Phinney, J. S. (1996). When we talk about

American ethnic groups, what do we mean?. American psychologist, 51(9), 918. Doi:

https://doi.org/10.1037//0003-

066x.51.9.918

Pieterse, A. L., Todd, N. R., Neville, H. A., \& Carter, R. T. (2012). Perceived racism and mental health among Black American adults: A metaanalytic review. Journal of Counseling Psychology, 59(1), 1.. Doi: https://doi.org/10.1037/a0026208

Pitre, C. C. (2014). Improving African American student outcomes: Understanding educational achievement and strategies to close opportunity gaps. Western Journal of Black Studies, 38(4), 209. Retrieved from https://search.proquest.com/docview/ 1649819273? accountid=14496

Radloff, L. S. (1977). The CES-D scale: a self-report depression scale for research in the general population. Applied psychological measurement, 1(3), 385-401. Doi:

https://doi.org/10.1177/01466216770 0100306

Sellers, R. M., \& Shelton, J. N. (2003). The role of racial identity in perceived racial discrimination. Journal of personality and social psychology, 84(5), 1079. Doi: https://doi.org/10.1037/00223514.84.5.1079

Smedley, B. D., Myers, H. F., \& Harrell, S. P. (1993). Minority-status stresses and the college adjustment of ethnic minority freshmen. The Journal of Higher Education, 64(4), 434-452.
Doi:

https://doi.org/10.1080/00221546.19 93.11778438

Smith, W., Hung, M., \& Franklin, J. (2011). Racial Battle Fatigue and the MisEducation of Black Men: Racial Microaggressions, Societal Problems, and Environmental Stress. The Journal of Negro Education, 80(1), 63-82. Doi: https://doi.org/10.1037/t60961-000

Smith, W. A., Yosso, T. J., \& Solórzano, D. G. (2011). Challenging racial battle fatigue on historically White campuses: A critical race examination of race-related stress. In Covert racism (pp. 211-238). Brill. Doi: https://doi.org/10.1163/ej.978900420 3655.i-461.82

Stallman, H. M. (2010). Psychological distress in university students: A comparison with general population data. Australian Psychologist, 45(4), 249-257. Doi:

https://doi.org/10.1080/00050067.20 10.482109

Sue, D. W. (2010). Microaggressions in everyday life: Race, gender, and sexual orientation. John Wiley \& Sons. Doi: https://doi.org/10.1086/663007

Trimble, J. (2007). Prolegomena for the connotation of construct use in the measurement of ethnic and racial identity. Journal of Counseling Psychology, 54, 247-258. doi::10.1037/0022-0167.54.3.247

Tushnet, M. (1994). The significance of Brown v. Board of Education. Virginia Law Review, 173-184. doi:: https://doi.org/10.2307/1073595

Watson, D., O'hara, M. W., Simms, L. J., Kotov, R., Chmielewski, M., McDade-Montez, E. A., \& Stuart, S. (2007). Development and validation 
of the Inventory of Depression and Anxiety Symptoms

(IDAS). Psychological assessment, 19(3), 253. Doi::

https://doi.org/10.1037/10403590.19.3.253

Warren, C. J. E. (1954). Brown v. board of education. United States Reports, 347(1954), 483.

Walters, P. B. (2001). Educational access and the state: Historical continuities and discontinuities in racial inequality in American education. Sociology of Education, 35-49. Doi:: https://doi.org/10.2307/2673252

Wildhagen, Tina. "Why does cultural capital matter for high school academic performance? An Empirical Assessment of Teacher-Selection and Self-Selection Mechanisms as Explanations of the Cultural Capital Effect." The Sociological Quarterly 50.1 (2009): 173-200. Doi: https://doi.org/10.1111/j.15338525.2008.01137.x

Wilson, V. R. (2007). The effect of attending an HBCU on persistence and graduation outcomes of AfricanAmerican college students. The Review of Black Political Economy, 34(1-2), 11-52. Doi: https://doi.org/10.1007/s12114-0079006-7 


\section{Appendix A}

\section{Perceived Social Support}

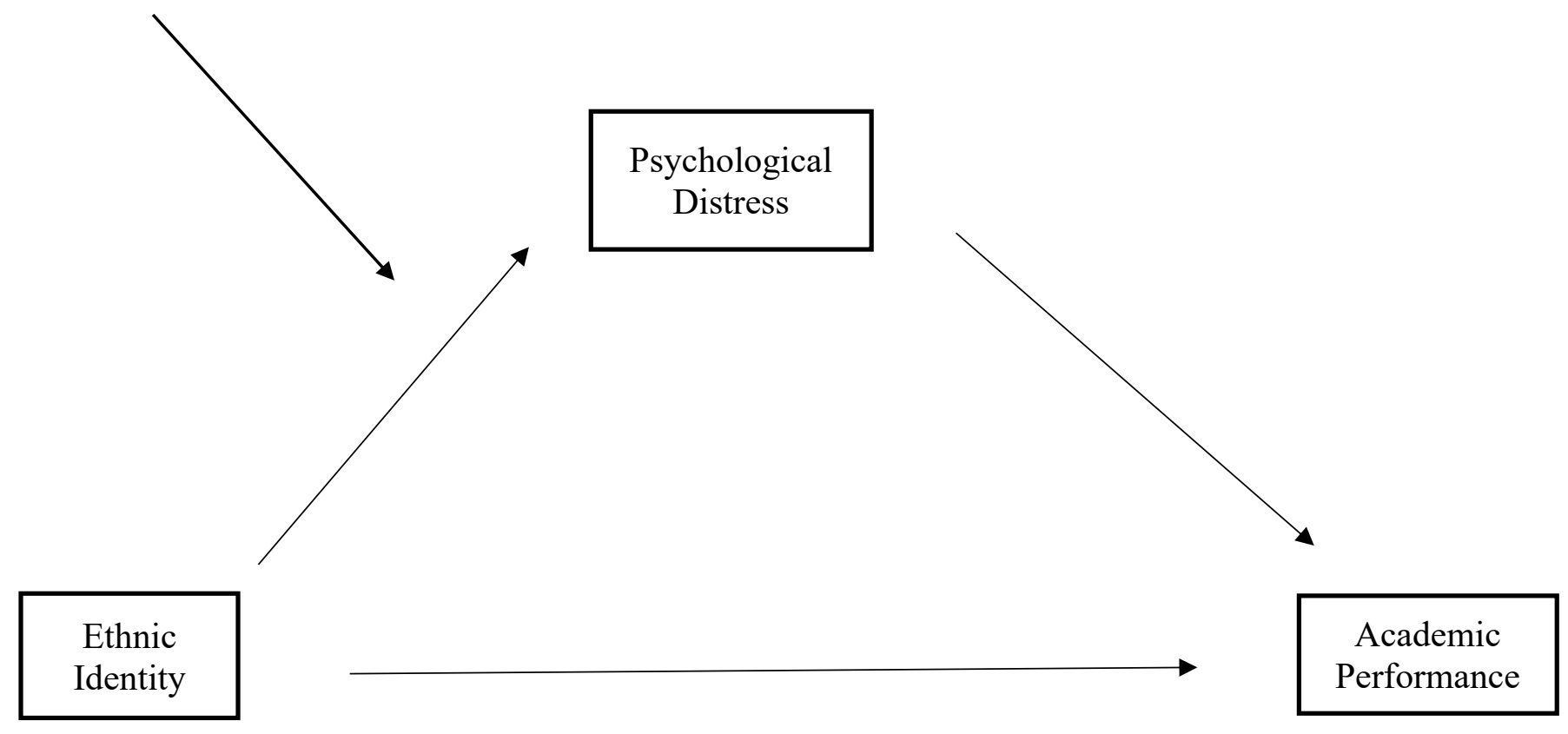


Table 1

Summary of PROCESS MACRO Analyses for Variables predicting Psychological Distress (CES-D) and Grade Point Average $(n=226)$

Variable

Psychological Distress Grade Point Average

\begin{tabular}{lllllll}
\hline & $R^{2}$ & $\Delta R^{2}$ & & $\beta$ & $R^{2}$ & $\Delta R^{2}$
\end{tabular}

Step 1

$.05 \quad .053$

Ethnic Identity

$.68^{*}$

Social Support

1.21

Step 2

$.00 \quad .001$

Psychological

Distress 
Table 2

Summary of PROCESS MACRO Analyses for Variables predicting Psychological Distress (IDAS) and Grade Point Average $(n=222)$

Step 1

Psychological Distress

Variable

\section{Grade Point Average}

\begin{tabular}{lll}
\hline & $R^{2}$ & $\Delta R^{2}$
\end{tabular}

$\begin{array}{ll}\text { Ethnic Identity } & -.15 \\ \text { Social Support } & .10\end{array}$

Step 2

$.13 \quad .128$

.15

10

Psychological Distress 